\section{Jornalistas: últimos românticos, trabalhadores de luta ou profissionais da objetividade?}

\section{Mônica MOURAO ${ }^{1}$}

ROXO, Marco. Companheiros em luta: a greve dos jornalistas de 1979. Niterói: Editora da UFF, 2012.

[Ser jornalista] é um estado de espírito, é uma disposição existencial. Eu já disse em outra entrevista que o jornalismo é uma das últimas profissões românticas - Alberto Dines

\begin{abstract}
Combatemos [na Folha de S. Paulo] muito essa ideia missionária. [...] Procuramos fazer uma desromantização da maneira de encarar a profissão - Otávio Frias Filho
\end{abstract}

Duas ideias literalmente opostas em relação ao papel do jornalista expõem a fratura que existe em relação à identidade desse grupo. É uma profissão romântica que atrai vocacionados? São funcionários de instituições midiáticas? Numa ponta deste fio, está uma concepção de jornalismo que o considera uma atividade feita por intelectuais imbuídos da missão de levar informação à sociedade; na outra, a noção de que jornalistas são profissionais ou, ainda, trabalhadores. As duas ideias foram materializadas nos depoimentos, publicados em 2003, de dois reconhecidos jornalistas ${ }^{2}$. Se, por um lado, isso mostra que ambas são contemporâneas, por outro, pode-se

1 Doutoranda em Comunicação pela Universidade Federal Fluminense. Contato: monicamourao@gmail.com

2 In ABREU, Alzira Alves de; LATTMAN-WELTMAN, Fernando; ROCHA, Dora (org). Eles mudaram a imprensa: depoimentos ao CPDOC. Rio de Janeiro: Editora FGV, 2003. pensar se há tanto uma clivagem temporal quanto uma identitária: existiu um momento histórico a partir do qual uma das concepções sobre ser jornalista se sobressaiu? $\mathrm{Ou}$ existem apenas momentos em que interessa mais, pelas disputas em questão, reivindicar tal ou qual identidade?

Marco Roxo, em seu livro "Companheiros em luta: a greve dos jornalistas de 1979", fruto de sua dissertação de mestrado, relaciona as questões colocadas acima com a greve dos jornalistas de São Paulo no período de abertura da ditadura militar brasileira. $\mathrm{O}$ acontecimento se complexifica ao se considerar o contexto político do país, de redemocratização, que inclui o fortalecimento dos sindicatos (a partir do novo sindicalismo) e uma profusão de greves de diferentes categorias, mas marcadamente a dos metalúrgicos do ABC paulista. Desse modo, o livro busca, além de contar e interpretar a greve de 1979, avaliar seu impacto na formação identitária de jornalistas e as imbricações políticas (inclusive partidárias) do movimento.

O livro aborda um tema pouco estudado, utilizando como fontes primárias depoimentos de líderes sindicais e jornalistas engajados na greve, ouvidos pelo autor ou, em sua maioria, publicados pelo jornal Unidade, do Sindicato dos Jornalistas Profissionais de São Paulo. Além deste periódico, também foram pesquisados os veículos sindicais Unidade Jornalística; Mural; Boletim do Comitê Unidade, Participação e Liberdade; e Unidade Sindical. Edições de veículos da imprensa conservadora e da alternativa também compõem o corpus utilizado para a análise da greve de 1979. A pesquisa abrange, na verdade, o período de maio de 1978 (momento de sucessão no sindicato e de greve dos metalúrgicos do $\mathrm{ABC}$ ), até dezembro de 1980, para procurar compreender os efeitos da greve para a categoria.

Os depoimentos citados pelo livro podem se tornar importantes fontes primárias para pesquisadores de temas correlatos. Ali, encontram-se posicionamentos institucionais do sindicato e de seus líderes, mas também de figuras proeminentes no período e, posteriormente, famosos jornalistas ou figuras públicas cruciais na história do país. Esse trabalho empírico de fôlego é respaldado teoricamente em autores da História Cultural, como Robert Darnton, e em marxistas que também dialogam com questões culturais, como E. P. Thompson e Antonio Gramsci.

O livro se divide em cinco capítulos. O primeiro, de contextualização mais geral, aborda a ditadura do governo Geisel, a esquerda do período e o novo sindicalismo. O segundo trata da imprensa, com um apanhado 
sobre veículos e mercado de trabalho em São Paulo, e do sindicato e seu jornal institucional. O capítulo 03 diz respeito à classe e sua representação, fazendo um retrospecto da greve anterior, de 1961, e seu uso como elemento de construção de uma identidade dos jornalistas como uma categoria de luta. Também aborda a criação e atuação do Conselho Consultivo de Representantes de Redação. Os dois últimos tratam dos antecedentes da greve e da greve em si, ambos colocando em discussão a identidade jornalística.

Nos estertores da ditadura, uma greve de jornalistas tem diferentes camadas de significados e implicações. Era mais uma das diversas categorias que entraram em greve naquele ano. Era uma categoria que, para se ver como classe trabalhadora, precisava reivindicar certa memória da greve de 1961. Era ainda o fim, segundo o autor, de um pacto entre jornalistas e proprietários de veículos, possível de ser mantido enquanto a censura de Estado foi uma inimiga comum.

Como consequência da derrota do movimento grevista, Marco Roxo aponta a demissão dos jornalistas mais politizados que, contrariando o senso comum, em sua maioria tinham passado por uma formação universitária. A política parecia ser empurrada das redações para os sindicatos, onde a disputa que acontecia em diferentes âmbitos da esquerda entre o velho Partido Comunista Brasileiro (PCB) e o recém-criado Partido dos Trabalhadores (PT) também dava o tom das divergências e composições. Assim, situado numa lacuna que é a bibliografia sobre a atuação sindical de jornalistas, o livro traz à tona esses aspectos políticos pouco abordados na historiografia da imprensa brasileira.

Além do caráter histórico da temática principal, a publicação aborda questões que permanecem atuais e, de tempos em tempos, voltam à pauta. No dia seguinte ao lançamento do livro, em 2013, trabalhadores da Empresa Brasil de Comunicação (EBC), que reúne emissoras públicas de rádio e televisão, entraram em greve. Como reivindicação, melhores salários, condições de trabalho e o fortalecimento da comunicação pública no Brasil. Em outro contexto macropolítico e diferente dos jornais privados, ainda assim podia-se ouvir - como eco de 1979, quem sabe? - que jornalistas eram trabalhadores.

Já em agosto de 2014, disputas entre os jornalistas do Rio de Janeiro em torno da atuação do seu Sindicato Municipal de Jornalistas Profissionais, acusado de apoiar pessoas que praticaram atos violentos contra profissionais da imprensa, gerou, entre outros encontros, uma assembleia em que a disputa de identidade transparecia em meio a pedidos de renúncia, de um lado, e de manutenção da diretoria, de outro. Quem são os jornalistas profissionais? Quais os limites de atuação de midiativistas, comunicadores populares e coletivos de comunicação, cujo número cresceu exponencialmente a partir das manifestações de junho de 2013?

Com questões impensáveis em 1979 ou disputas antigas com nova roupagem, o jornalismo e o papel social do jornalista seguem desafiando pesquisadores e comunicadores. Clamam por olhares, abordagens, interpretações. Este é um trabalho constante, que se "Companheiros em luta" não pode responder, por sua limitação temporal, certamente se constitui num importante ponto de partida.

\section{Referências bibliográficas}

ABREU, Alzira Alves de; LATTMAN-WELTMAN, Fernando; ROCHA, Dora (Orgs.). Eles mudaram a imprensa: depoimentos ao CPDOC. Rio de Janeiro: Editora FGV, 2003. 